Revista Brasileira de Meteorologia, v.27, n.3, 272 - 280, 2012

\title{
EVALUATION OF SIX EMPIRICAL EVAPOTRANSPIRATION EQUATIONS - CASE STUDY: CAMPOS DOS GOYTACAZES/RJ
}

\author{
LÁZARO COSTA FERNANDES ${ }^{1}$, CÉLIA MARIA PAIVA ${ }^{2}$, OTTO CORREAA ROTUNNO FILHO ${ }^{1}$ \\ ${ }^{1}$ Universidade Federal do Rio de Janeiro, Programa de Engenharia Civil (UFRJ/COPPE), Laboratório de \\ Recursos Hídricos e Meio Ambiente, Rio de Janeiro, RJ, Brasil \\ ${ }^{2}$ UFRJ, Departamento de Meteorologia, Rio de Janeiro, RJ, Brasil \\ lazaro@coc.ufrj.br, celia@1ma.ufrj.br, otto@coc.ufrj.br \\ Received March 2009 - Accepted February 2012
}

\begin{abstract}
The evapotranspiration is a component of the water balance constituting a major challenge in its quantification. The complex physical processes involved in its effective determination on a large scale have spurred scientists to often make use of empirical equations, which have inherent limitations with regard to their applicability as descriptors of the evapotranspiration behavior in different regions across the world. This study was performed for the Campos dos Goytacazes region, in Rio de Janeiro state. It is proposed to investigate and to evaluate the performance of six empirical equations in contrast to FAO56-Penman-Monteith equation. The results indicated that the differences observed between the values obtained using the empirical models applied in this study and the values calculated by the FAO56-Penman-Monteith equation were greater than $10 \%$, which means an error of about 0.5 mm.day ${ }^{-1}$.
\end{abstract}

Keywords: evapotranspiration, FAO56-Penman-Monteith, empirical equations.

RESUMO: AVALIAÇÃO DE SEIS EQUAÇÕES EMPÍRICAS DE EVAPOTRANSPIRAÇÃO DIÁRIA - ESTUDO DE CASO: CAMPOS DOS GOYTACAZES/RJ

A evapotranspiração é um dos componentes do balanço hídrico que representa grande desafio em sua quantificação. Os processos físicos complexos envolvidos na sua determinação em larga escala têm estimulado cientistas a fazer o uso, muitas vezes, de equações empíricas, que apresentam intrínseca limitação no que concerne à aplicabilidade como descritores do comportamento da evapotranspiração em diferentes regiões do mundo. Este estudo foi realizado para a região de Campos dos Goytacazes, no estado do Rio de Janeiro, e propõe-se a investigar e avaliar o desempenho de seis equações empíricas em contraste com a equação FAO56-Penman-Monteith. Os resultados indicaram que as diferenças observadas entre os valores obtidos com os modelos empíricos aplicados neste estudo e os valores calculados pela equação de FAO56-Penman-Monteith foram maiores que $10 \%$, o que significa um erro em torno de $0,5 \mathrm{~mm} \cdot \mathrm{dia}^{-1}$.

Palavras -chaves: evapotranspiração, FAO56-Penman-Monteith, equações empíricas.

\section{INTRODUCTION}

Evapotranspiration is a major component of the land surface water balance allowing the transference of water and energy to the atmosphere. The physical phenomenon involves soil, plants and air and the corresponding meteorological conditions. The evapotranspiration rate is normally expressed in millimeters $(\mathrm{mm})$ per unit time. The rate expresses the amount of water lost from a cropped surface in units of water depth. The time unit can be an hour, day, decade, month or even an entire growing period or year (Allen et al., 1998).

The calculation of reliable estimates of basin-wide evapotranspiration remains one of the most difficult questions for the hydrologic science. The procedure to estimate evapotranspiration is particularly important in water budget studies to the consumptive use as required for example by ecological and water resources planning studies (Dias and Kan, 1999). Referring to agricultural production, its measurements is 
greatly relevant, where it is essential for determining crop water demand and consequently for designing and managing irrigation system (Gavilán, 2002, apud López-Urrea et al., 2006).

Evapotranspiration is not easy to measure. Specific devices and accurate measurements of various physical parameters or the soil water balance in lysimeters are required to determine evapotranspiration. The methods are often expensive, demanding in terms of accuracy of measurements and can only be fully exploited by well-trained personnel. Although the methods are inappropriate for routine measurements, they remain important for the validation of ET estimates obtained by more indirect methods (Allen et al., 1998).

According to Allen et al. (1998), evapotranspiration rates of the various crops are related to the evapotranspiration rate from the reference surface (ETo) by means of crop coefficients. The concept of a reference surface was introduced due to the need to define unique evaporation parameters for each crop and stage of growth. Grass and alfafa are well-studied crops regarding their aerodynamic and surface characteristics and are accepted worldwide as references surfaces (Burman and Pochop, 1994). Because the resistance to diffusion of water vapor strongly depends on crop height, ground cover, leaf area index and soil moisture condition, the associated canopy and aerodynamic resistance will vary appreciably with time. Consequently, the characteristics of the reference surface crop should be well defined and fixed. To avoid problems of local calibration which would require demanding and expensive studies, a hypothetical grass reference has been selected. The FAO Expert Consultation on Revision of FAO Methodologies for Crop Water Requirements accepted the following unambiguous definition for the reference surface:

"A hypothetical reference crop with an assumed crop height of $0.12 \mathrm{~m}$, a fixed surface resistance of $70 \mathrm{~s}^{-1} \mathrm{~m}^{-1}$ and an albedo of 0.23 ".

The reference surface closely resembles an extensive surface of green grass of uniform height, actively growing, completely shading the ground and with adequate supply of water.

In the attempt to provide an adequate answer for the previously mentioned problem, the FAO Penman-Monteith method was developed and selected as an alternative by which the evapotranspiration of this reference surface (ETo) can be unambiguously determined, and as the method which provides consistent ETo values across all regions and climates. However, this model presents a level of input data requirement, not always available in some regions, which make its application difficult. In these cases, it is necessary to use simplified or empirical equations. These kind of relationships were often subject to rigorous local calibrations and validation in order to have limited global validity. Testing the accuracy of the methods under a new set of climatic condition is frequently needed (Allen et al., 1998).

A large number of empirical methods have been used by numerous scientists and specialists worldwide to estimate evapotranspiration from different climatic variables. Oudin et al. (2004), Fernandes (2006) and Barros (2012) reviewed commonly used equations in the literature. Such practical application is motivated due to the lack of data that avoid the use of more accurate equations. Therefore, in this paper, to provide an adequate support for users that are exposed to different levels of data availability, the performance of six empirical equations for estimating evapotranspiration are investigated for the case study of Campos dos Goytacazes city located at Rio de Janeiro state, as initially developed in Fernandes (2006), using the recommended FAO56-Penman-Monteith equation (Allen et $a l ., 1998)$ as a reference for comparison.

The evapotranspiration was estimated by six empirical equations, divided in two groups (according to Burman and Pochop, 1994; Jensen et al., 1990; Pereira et al., 2002 and Sediyama et al., 1997), namely: i) temperature methods Camargo and Hargreaves-Samani and ii) radiation methods Makkink, Jensen-Haise, Priestley-Taylor and Hargreaves. Such equations were chosen because of the simplicity of calculations, since the meteorological data required are easily obtained.

The evaluation of these equations was initially made by Fernandes (2006). The current study aims to further contribute to the results already achieved by the previous study, and it is part of a project that intends to evaluate the performance of different equations of estimate of ETo, with the purpose to subsidize the use of these equations in the different Brazilian climatic conditions.

\section{MATERIALS AND METHODS}

This study was carried based on data obtained through the use of a climatological weather station located at the city of the Campos dos Goytacazes (state of Rio de Janeiro - Southeast of Brazil). The geographical coordinates are latitude $21^{\circ} 48^{\prime} \mathrm{S}$ and longitude $41^{\circ} 20^{\prime} \mathrm{W}$ and the altitude is $11 \mathrm{~m}$ above sea level. The weather station surroundings are representative of sugar cane farm.

Climatic data used in ETo calculation was daily collected during the period between March of 1975 and December of 2003. They are as follows: net radiation (W. $\left.\mathrm{m}^{-2}\right)$; soil heat flux density $\left(\mathrm{W} . \mathrm{m}^{-2}\right)$; solar radiation $\left(\mathrm{W} \cdot \mathrm{m}^{-2}\right)$; sunshine duration (hours); air temperature $\left({ }^{\circ} \mathrm{C}\right)$; relative air humidity $(\%)$; wind speed at $2 \mathrm{~m}$ height $\left(\mathrm{m} \cdot \mathrm{s}^{-1}\right)$; atmospheric pressure (hPa).

The climate in Campos dos Goytacazes is characterized by air temperature in the hottest month (February) ranging between $22.4^{\circ} \mathrm{C}$ and $32.5^{\circ} \mathrm{C}$ and in the coldest month (July) with values between 16.1 and $26.8^{\circ} \mathrm{C}$, achieving an annual mean temperature of $24.8^{\circ} \mathrm{C}$. The monthly average relative 
humidity varies between 57.0\% (July) and 64.0\% (December), with values lower than $60 \%$ between June and August. The mean annual evaporation and rainfall are $2039.9 \mathrm{~mm}$ and 780.6 $\mathrm{mm}$, respectively, what it causes a substantial water deficit in the reservoir of the ground. The monthly average speed of the wind varies between $4.9 \mathrm{~km} \cdot \mathrm{h}^{-1}$ (June) and $8.9 \mathrm{~km} \cdot \mathrm{h}^{-1}$ (October).

According to Allen et al. (1998) the FAO56-PenmanMonteith should be considered as the reference method. The equations are given as follows below.

\subsection{FAO56-Penman-Monteith}

The FAO56-Penman-Monteith Equation 1 is expressed as (Allen et al., 1998):

$$
\begin{aligned}
\mathrm{ET}_{\mathrm{o}} & =\frac{0.408 \Delta(\mathrm{Rn}-\mathrm{G})+\gamma(900 /(\mathrm{Tmean}+273)) \mathrm{U}_{2}(\mathrm{es}-\mathrm{e})}{\Delta+\gamma(1+0.34 \mathrm{U} 2)} \\
\Delta & =\lambda . \mathrm{es} /\left(\mathrm{Rv} T m e a n^{2}\right) \\
\gamma & =\mathrm{cp} . \mathrm{P} /(\varepsilon . \lambda) \\
\mathrm{es} & =2.53 \times 10^{8} \cdot \exp (-5420 /(\text { Tmean }+273)) \\
\mathrm{e} & =\mathrm{UR} . \mathrm{es}
\end{aligned}
$$

where ETo is the reference evapotranspiration $\left(\mathrm{mm}^{\mathrm{day}}{ }^{-1}\right) ; \Delta$ is the slope of the vapor pressure curve $\left(\mathrm{kPa}^{.}{ }^{\circ} \mathrm{C}^{-1}\right)$; $\mathrm{Rn}$ is the net radiation at the crop surface (MJ. $\mathrm{m}^{-2} \cdot$ day $\left.^{-1}\right) ; \mathrm{G}$ is the soil heat flux density (MJ. $\mathrm{m}^{-2}$.day $\left.{ }^{-1}\right)$; Tmean is the daily mean air temperature at $2 \mathrm{~m}$ height $\left({ }^{\circ} \mathrm{C}\right) ; \mathrm{U} 2$ is the wind speed at $2 \mathrm{~m}$ height $\left(\mathrm{m} . \mathrm{s}^{-1}\right)$; es is the saturation vapor pressure $(\mathrm{kPa})$; e is the actual vapor pressure $(\mathrm{kPa})$; UR is the relative humidity; $(\mathrm{es}-\mathrm{e})$ is the saturation vapor pressure deficit $(\mathrm{kPa}) ; \gamma$ is the psychrometric constant $\left(\mathrm{kPa}^{\circ} \mathrm{C}^{-1}\right) ; \lambda$ is the heat required to vaporize free water $\left(2450 \mathrm{~kJ}^{-\mathrm{m}^{-2}} \cdot \mathrm{day}^{-1}\right)$; $\mathrm{cp}$ is the specific heat at constant pressure $\left(1.01 \mathrm{~kJ} \cdot \mathrm{kg}^{-1} \cdot \mathrm{K}^{-1}\right)$; $\mathrm{P}$ is the atmospheric pressure $(\mathrm{kPa}) ; \varepsilon$ is the ratio molecular weight of water vapor/ dry air, which is equal to 0.622 .

According to Burman and Pochop (1994), Jensen et al. (1990) and Sediyama et al. (1997), the net radiation is expressed as:

$R_{n}=(1-A) \cdot R_{s}-\left[(0.1+0.9 n) \cdot\left(0.34-0.14 e^{0.5}\right) \cdot \sigma \cdot\left(T_{\text {mean }}+273\right)^{4}\right]$

where Rs is the global radiation at surface $\left(\mathrm{MJ} \cdot \mathrm{m}^{-2}\right.$.day $\left.{ }^{-1}\right)$; A is the albedo or canopy reflection coefficient; $n$ is the actual duration of sunshine (hours); $\sigma$ is the Stefan-Boltzmann constant, which is equal to $5.67 \times 10^{-8} \mathrm{~W} \cdot \mathrm{m}^{-2} \cdot \mathrm{K}^{-4}$.

\subsection{Makkink}

The Makkink equation is expressed as (Sediyama et al., 1997):

$$
\begin{aligned}
& \mathrm{ETo}=0.61 \mathrm{~W} . \mathrm{Rs}-0.12 \\
& \mathrm{~W}=\Delta /(\Delta+\gamma)
\end{aligned}
$$

where $\mathrm{W}$ is the index that depends on the psychrometric constant $\gamma\left(\mathrm{kPa} \cdot \mathrm{K}^{-1}\right)$ and slope of the vapor pressure curve $\Delta\left(\mathrm{kPa} \cdot \mathrm{K}^{-1}\right)$.

\subsection{Jensen-Haise}

The Jensen-Haise equation is expressed as (Sediyama et al., 1997):

$$
\text { ETo }=(0.0252 \text { Tmean }+0.078) \cdot \text { Rs }
$$

\subsection{Camargo}

The Camargo equation is expressed as (Sediyama et al., 1997):

$$
\begin{aligned}
& \mathrm{ET}_{\mathrm{o}}=\mathrm{f} \cdot \text { Tmean } \cdot \text { Ra.ND } \\
& \mathrm{Ra}=15.34 \mathrm{~d}_{\mathrm{r}} \cdot(\omega \cdot \operatorname{sen} \varphi \cdot \operatorname{sen} \delta+\cos \varphi \cdot \cos \delta \cdot \operatorname{sen} \omega) \\
& \mathrm{dr}=1+\cos (0.0172 \mathrm{~J})
\end{aligned}
$$

where $\mathrm{f}$ is the empirical factor, which is equal to 0.01 ; $\mathrm{Ra}$ is the extraterrestrial radiation $\left(\mathrm{mm} \cdot \mathrm{day}^{-1}\right)$; ND is the length of the time interval (day); dr is the inverse relative distance Earth-Sun; $\omega$ is the hour angle (rad); $\varphi$ is the latitude (rad); $\delta$ is the solar declination ( $\mathrm{rad}$ ); $\mathrm{J}$ is the number of the day in the year between 1 (January $1^{\text {st }}$ ) and 365 or 366 (December $31^{\text {st }}$ ).

\subsection{Priestley-Taylor} et al., 1997):

The Priestley-Taylor equation is expressed as (Sediyama

$$
\mathrm{ETo}=\alpha . \mathrm{W} .\left(\mathrm{R}_{\mathrm{n}}-\mathrm{G}\right)
$$

where $\alpha$ is the calibration constant, which is equal to 1.26 (Jensen et al., 1990; Pereira et al., 2002).

\subsection{Hargreaves}

The Hargreaves equation is expressed as (Jensen et al., 1990):

$$
\mathrm{ETo}=0.0135 . \text { Rs. }(\text { Tmean }+17.8)
$$




\subsection{Hargreaves-Samani}

The Hargreaves-Samani equation is expressed as (Allen et al., 1998):

$$
\mathrm{ET}_{\mathrm{o}}=0.0023(\mathrm{Tmean}+17.8) \cdot(\mathrm{Tmax}-\mathrm{Tmin})^{0.5} \cdot \mathrm{Ra}
$$

where Tmax is the daily maximum temperature $\left({ }^{\circ} \mathrm{C}\right)$; Tmin is the daily minimum temperature $\left({ }^{\circ} \mathrm{C}\right)$.

According to other previous papers (Willmott, 1982; Box et al., 1989, apud López-Urrea et al., 2006), the relationships between daily ETo values estimated by FAO56- PenmanMonteith equation and each of the six methods studied were established through statistical regression analysis, including the coefficient of determination $\left(\mathrm{R}^{2}\right)$, root mean square error (RMSE), relative error (RelRMSE) and index of agreement (d). The RMSE was calculated as:

$$
\operatorname{RMSE}=\left[\mathrm{N}^{-1} \Sigma\left(\mathrm{P}_{\mathrm{i}}-\mathrm{O}_{\mathrm{i}}\right)^{2}\right]^{2}
$$

where RMSE is the root mean square error $\left(\mathrm{mm} \cdot \mathrm{day}^{-1}\right)$; $\mathrm{N}$ is the number of observations; $\mathrm{P}_{\mathrm{i}}$ are ETo values calculated by other methods (mm.day $\left.{ }^{-1}\right) ; \mathrm{O}_{\mathrm{i}}$ are ETo values calculated by FAO56Penman-Monteith equation $\left(\mathrm{mm} \cdot \mathrm{day}^{-1}\right)$.

The mean square error expressed as a percentage of the ETo mean value estimated by FAO56-Penman-Monteith equation $\left(\mathrm{O}_{\text {avg }}\right)$ was used as a measure of relative error:

$$
\text { RelRMSE }=\mathrm{RMSE} / \mathrm{O}_{\mathrm{avg}}
$$

The index of agreement (d) was given by:

$$
\begin{aligned}
& \mathrm{d}=1-\left[\Sigma\left(\mathrm{P}_{\mathrm{i}}-\mathrm{O}_{\mathrm{i}}\right)^{2} / \Sigma\left(\left|\mathrm{P}_{\mathrm{i}}-\mathrm{O}_{\text {avg }}\right|+\left|\mathrm{O}_{\mathrm{i}}-\mathrm{O}_{\text {avg }}\right|\right)^{2}\right] \\
& 0 \leq \mathrm{d} \leq 1
\end{aligned}
$$

where perfect agreement would exist between $\mathrm{P}$ and $\mathrm{O}$ if $\mathrm{d}$ equals to 1.

\section{RESULTS AND DISCUSSION}

\subsection{Evaluation of ETo calculation methods}

As previously stated, the relationship between daily ETo values estimated by FAO56-Penman-Monteith equation and each of the six methods studied was evaluated. The evapotranspiration estimated by the FAO56-Penman-Monteith equation was taken as the dependent variable while the evapotranspiration estimated by each of the six methods was taken as the independent variable.

The analysis evaluation was conducted for 4026 daily observation carried out during 11 years. Table 1 shows the results for this comparison, using simple statistical regression analysis, indicating error estimation and index of agreement.

The Makkink, Priestley-Taylor and Hargreaves methods achieved the best performances, with higher coefficients of determination (over 0.9) and indices of agreement close to 1. They present RMSE lower than $1 \mathrm{~mm}$.day ${ }^{-1}$, which corresponds to a relative error under $20 \%$. After Hargreaves, Priestley-Taylor and Makkink methods, Hargreaves-Samani and Camargo approaches presented better behavior. They presented RMSE

\begin{tabular}{|c|c|c|c|c|c|c|c|c|}
\hline \multirow[t]{2}{*}{ Methods } & \multirow{2}{*}{\begin{tabular}{c|c|}
$P_{\text {avg }}$ \\
$\left(m m \cdot\right.$ day $\left.^{-1}\right)$
\end{tabular}} & \multirow{2}{*}{$\begin{array}{c}\mathrm{P}_{\mathrm{avg}} / \mathrm{O}_{\mathrm{avg}} \\
(\%)\end{array}$} & \multicolumn{3}{|c|}{ ETo (FAO56-Penman-Monteith) = A + B.ETo (method) } & \multirow{2}{*}{$\begin{array}{c}\text { RMSE } \\
\left(\mathrm{mm} \cdot \text { day }^{-1}\right)\end{array}$} & \multirow{2}{*}{$\begin{array}{c}\text { RelRMSE } \\
(\%)\end{array}$} & \multirow[t]{2}{*}{$\mathrm{d}$} \\
\hline & & & $\mathrm{A}\left(\mathrm{mm} \cdot \mathrm{day}^{-1}\right)$ & B (mm.day $\left.{ }^{-1}\right)$ & $\mathrm{R}^{2}\left(\mathrm{~mm} \cdot\right.$ day $\left.^{-1}\right)$ & & & \\
\hline Hargreaves & 4.39 & 110 & 0.18 & 0.87 & 0.93 & 0.63 & 16.73 & 0.96 \\
\hline Priestley-Taylor & 4.42 & 111 & 0.43 & 0.81 & 0.91 & 0.71 & 17.89 & 0.95 \\
\hline Makkink & 3.31 & 83 & 0.12 & 1.17 & 0.93 & 0.8 & 19.86 & 0.92 \\
\hline Hargreaves-Samani & 4.11 & 103 & -0.64 & 1.12 & 0.67 & 0.9 & 22.97 & 0.88 \\
\hline Camargo & 3.45 & 87 & -0.18 & 1.21 & 0.53 & 1.2 & 30.07 & 0.75 \\
\hline Jensen-Haise & 5.43 & 136 & 0.34 & 0.67 & 0.94 & 1.63 & 41.03 & 0.84 \\
\hline \multicolumn{9}{|c|}{$\begin{array}{l}\text { Regression analysis of the values calculated by various methods over those calculated by FAO56-Penman-Monteith. Number of observations: } \\
4026 \text {; } \mathrm{P}_{\text {avg: }} \text { : mean of the values calculated by various methods; } \mathrm{O}_{\text {avg }} \text { : mean of the values calculated by FAO56-Penman-Monteith }\left(3.98 \mathrm{~mm}^{-1} \text { - day }{ }^{-1}\right) \text {; } \\
\text { A: ordinate at the origin; } \mathrm{B} \text { : slope regression coefficient; } \mathrm{R}^{2} \text { : coefficient of determination; RMSE: root mean squared error; RelRMSE: relative } \\
\text { error; } \mathrm{d} \text { : index of agreement. }\end{array}$} \\
\hline
\end{tabular}
values close to $1 \mathrm{~mm}^{-d a y}{ }^{-1}$, with relative errors around $20 \%$ and $30 \%$, respectively. The indices of agreement presented values of 0.75 and 0.88 , respectively. The Jensen-Haise equation

Table 1 - Evaluation of the various methods for calculating mean daily ETo during the entire year. 


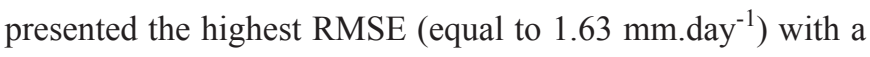
relative error over $40 \%$ and an index of agreement equal to 0.84 . On the other hand, its coefficient of determination was over 0.9 .

The Hargreaves-Samani method only overestimates FAO56-Penman-Monteith equation by 3\%; Hargreaves and Priestley-Taylor methods showed significant overestimations (around 10\%); Jensen-Haise equation presented the highest overestimation with value equal to $36 \%$; and Camargo and Makkink produced a significant underestimation (13-17\%).

Figure 1 shows graphs of the regressions for the three methods that presented the best performances when compared to FAO56-Penman-Monteith equation. The Hargreaves (1982) method (Figure 1a) gives a small overestimation under $1 \mathrm{~mm}$. day $^{-1}$ approximately; between this value and $2 \mathrm{~mm}^{-d a y}{ }^{-1}$, the slope of the straight line is near 1 and coincides perceptibly to the intercept equal to zero, which indicates a good performance of Hargreaves method in this interval. Above $2 \mathrm{~mm}^{-d a y}{ }^{-1}$ it underestimates values obtained by FAO56-Penman-Monteith equation. The Priestley-Taylor method (Figure 1b) overestimates FAO56-Penman-Monteith equation under $3 \mathrm{~mm}^{- \text {day }^{-1} \text { and }}$ underestimates above this value, while Makkink method always overestimates FAO56-Penman-Monteith equation (Figure 1c).

In summary, the results showed that good coefficients of determination and indices of agreement (both of them over 0.9) were obtained by Hargreaves, Priestley-Taylor and Makkink methods, with relative errors and overestimations under $20 \%$. The Hargreaves-Samani and Camargo methods presented poorer coefficients of determination in comparison to the previous three methods with values under 0.8 and relative errors between approximately $20-30 \%$. On the other hand, the Jensen-Haise method obtained a good coefficient of determination (over 0.9 ), but it is limited by its high overestimation and significative relative error (around 40\%).

The relationship between daily ETo values estimated by FAO56-Penman-Monteith equation and the six methods studied was evaluated during two different periods of year, one of high evaporative demand between the months of October to March, which englobes the rainy season; and the other one of weak evaporative demand between April to September, which is a period with not much rainfall.

Table 2 shows the results for comparing the six evaluated methods for calculation of evapotranspiration in contrast to FAO56-Penman-Monteith equation in the period from October to March during the 11 years of recorded data used in this study.

The results are similar for the period that englobes the whole year. The Hargreaves, Priestley-Taylor and Makkink methods achieved once more the best performances, with coefficients of determination and indices of agreement over 0.9 . The RMSE and the relative error were equal to or less than $1 \mathrm{~mm}^{\text {day }}{ }^{-1}$ and $20 \%$, respectively. Hargreaves-Samani

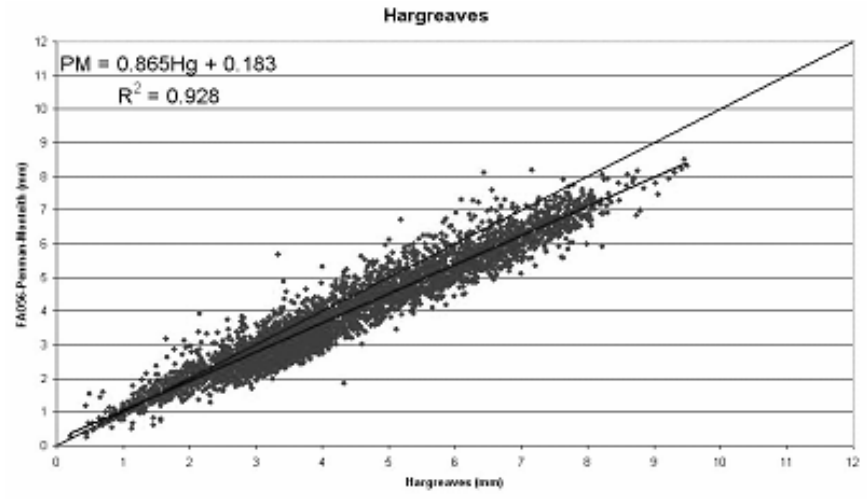

(a)

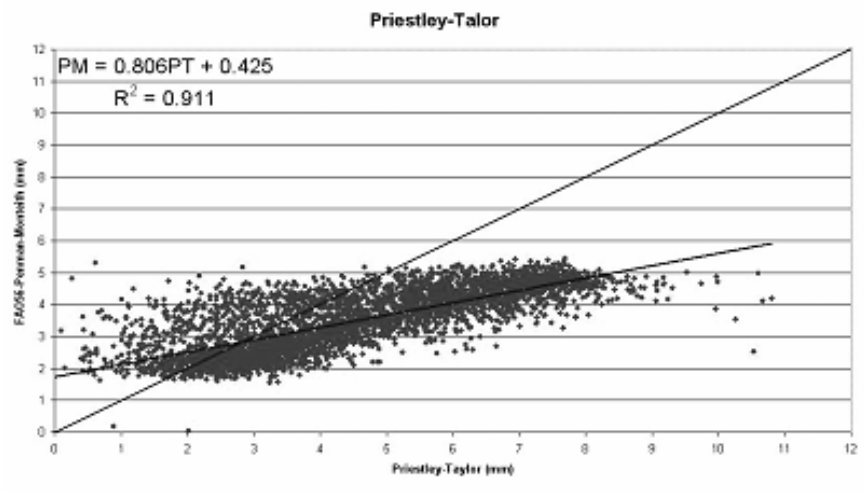

(b)

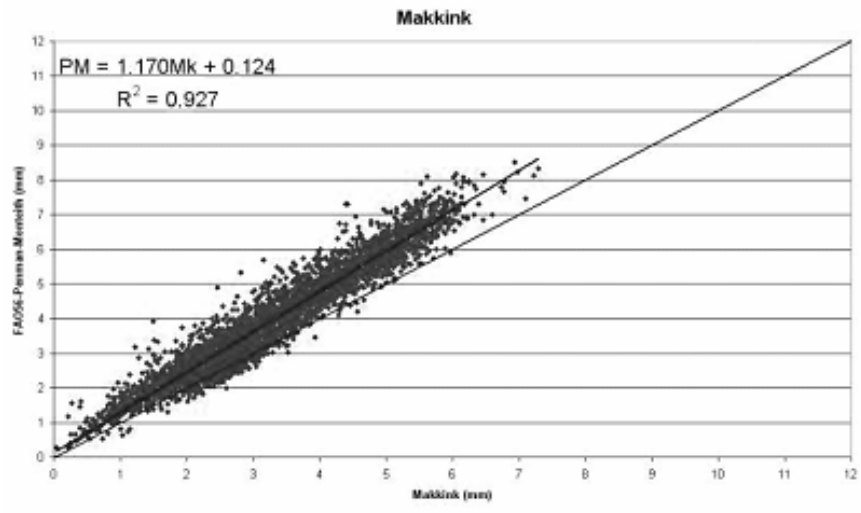

(c)

Figure 1 - Comparison between ETo values estimated by FAOPenman-Monteith equation and those calculated for the three methods that performed the best.

and Camargo were methods presented then the second lowest

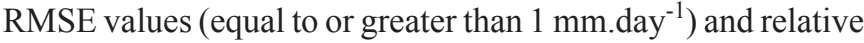
errors between 20 and $30 \%$ approximately. The coefficient of determination presented values under 0.6. Once again, the 
Table 2 - Evaluation of the various methods for calculating mean daily ETo in the period of high evaporative demand.

\begin{tabular}{|c|c|c|c|c|c|c|c|c|}
\hline Methods & $P_{\text {avg }}$ & $\mathrm{P}_{\mathrm{avg}} / \mathrm{O}_{\mathrm{avg}}$ & ETo (FAO56-P & an-Monteith) = & B.ETo (method) & RMSE & RelRMSE & d \\
\hline & $\left(m m \cdot\right.$ day $\left.^{-1}\right)$ & $(\%)$ & $\mathrm{A}\left(\mathrm{mm} \cdot \mathrm{day}^{-1}\right)$ & $\mathrm{B}\left(\mathrm{mm} \mathrm{day}^{-1}\right)$ & $\mathrm{R}^{2}\left(\mathrm{~mm}\right.$ day $\left.^{-1}\right)$ & $\left(m m \cdot\right.$ day $\left.^{-1}\right)$ & $(\%)$ & \\
\hline Hargreaves & 5.31 & 109 & -0.16 & 1.12 & 0.93 & 0.68 & 13.91 & 0.96 \\
\hline Priestley-Taylor & 5.58 & 115 & 0.34 & 1.08 & 0.91 & 0.89 & 18.35 & 0.93 \\
\hline Makkink & 3.97 & 81 & -0.12 & 0.84 & 0.94 & 1 & 20.51 & 0.89 \\
\hline Hargreaves-Samani & 4.88 & 100 & 2.59 & 0.47 & 0.54 & 1.06 & 21.83 & 0.96 \\
\hline Camargo & 4.29 & 88 & 3.39 & 0.18 & 0.35 & 1.46 & 29.87 & 0.46 \\
\hline Jensen-Haise & 6.66 & 137 & -0.46 & 1.46 & 0.94 & 1.99 & 40.81 & 0.78 \\
\hline $\begin{array}{l}\text { Regression analysis } \\
\text { 1984; } \mathrm{P}_{\text {avg }} \text { : mean of } \\
\text { A: ordinate at the o } \\
\text { error; } \mathrm{d} \text { : index of ag }\end{array}$ & $\begin{array}{l}\text { f the values } \\
\text { he values cal } \\
\text { gin; B: slop } \\
\text { ement. }\end{array}$ & $\begin{array}{l}\text { alculated } \\
\text { lated by } \\
\text { egression }\end{array}$ & $\begin{array}{l}\text { various method } \\
\text { ous methods; O } \\
\text { ffficient; } \mathrm{R}^{2} \text { : co }\end{array}$ & $\begin{array}{l}\text { those calcul } \\
\text { an of the val } \\
\text { nt of determi }\end{array}$ & $\begin{array}{l}\text { y FAO56-Pen } \\
\text { lculated by FA } \\
\text {; RMSE: root }\end{array}$ & $\begin{array}{l}\text { Monteith; I } \\
\text {-Penman-M } \\
\text { n squared e }\end{array}$ & $\begin{array}{l}\text { nber of obs } \\
\text { eith }(4.87 \text { r } \\
\text { r; RelRMS }\end{array}$ & $\begin{array}{l}\text { ations } \\
\text { day }^{-1} \text { ) } \\
\text { elative }\end{array}$ \\
\hline
\end{tabular}

Table 3 - Evaluation of the various methods for calculating mean daily ETo in the period of low evaporative demand.

\begin{tabular}{|c|c|c|c|c|c|c|c|c|}
\hline \multirow[t]{2}{*}{ Methods } & \multirow{2}{*}{$\begin{array}{c}\mathrm{P}_{\mathrm{avg}} \\
\left(\mathrm{mm} \text { day }^{-1}\right)\end{array}$} & \multirow{2}{*}{$\begin{array}{c}\mathrm{P}_{\mathrm{avg}} / \mathrm{O}_{\mathrm{avg}} \\
(\%)\end{array}$} & \multicolumn{3}{|c|}{ ETo (FAO56-Penman-Monteith) = A + B.ETo (method) } & \multirow{2}{*}{$\begin{array}{c}\text { RMSE } \\
\left(\mathrm{mm} \text { day }^{-1}\right)\end{array}$} & \multirow{2}{*}{$\begin{array}{c}\text { RelRMSE } \\
(\%)\end{array}$} & \multirow[t]{2}{*}{$\mathrm{d}$} \\
\hline & & & $\mathrm{A}\left(\mathrm{mm}_{\mathrm{day}}{ }^{-1}\right)$ & $\mathrm{B}\left(\mathrm{mm}_{\mathrm{day}}{ }^{-1}\right)$ & $\mathrm{R}^{2}\left(\mathrm{~mm} \cdot \mathrm{day}^{-1}\right)$ & & & \\
\hline Priestley-Taylor & 3.25 & 105 & 0.19 & 0.99 & 0.81 & 0.53 & 17.3 & 0.94 \\
\hline Hargreaves & 3.46 & 112 & 0.36 & 1 & 0.85 & 0.59 & 19.07 & 0.93 \\
\hline Makkink & 2.65 & 86 & 0.26 & 0.77 & 0.85 & 0.6 & 19.41 & 0.9 \\
\hline Hargreaves-Samani & 3.34 & 108 & 1.63 & 0.56 & 0.56 & 0.74 & 23.96 & 0.96 \\
\hline Camargo & 2.62 & 85 & 1.65 & 0.31 & 0.42 & 0.94 & 30.48 & 0.61 \\
\hline Jensen-Haise & 4.2 & 136 & 0.17 & 1.3 & 0.86 & 1.27 & 41.02 & 0.78 \\
\hline \multicolumn{9}{|c|}{$\begin{array}{l}\text { Regression analysis of the values calculated by various methods over those calculated by FAO56-Penman-Monteith; Number of observations: } \\
2042 ; \mathrm{P}_{\text {avg }} \text { : mean of the values calculated by various methods; } \mathrm{O}_{\text {avg }} \text { : mean of the values calculated by FAO56-Penman-Monteith }\left(3.09 \mathrm{~mm}^{-1 a y}{ }^{-1}\right) \text {; } \\
\text { A: ordinate at the origin; B: slope regression coefficient; } \mathrm{R}^{2} \text { : coefficient of determination; RMSE: root mean squared error; RelRMSE: relative } \\
\text { error; d: index of agreement. }\end{array}$} \\
\hline
\end{tabular}

Jensen-Haise equation presented the highest RMSE (equal $1.99 \mathrm{~mm}^{- \text {day }^{-1}}$ ), a relative error over $40 \%$, a coefficient of determination over 0.9 and an index of agreement around 0.8 .

The Hargreaves and Priestley-Taylor methods generated significant overestimations (equal to or greater than 9\%); Jensen-Haise equation showed the highest overestimation with value equal to 37\%; and Camargo and Makkink produced a significative underestimation (12-19\%).

Figure 2 shows graphs for the regression analysis conducted for the three methods that demonstrated the best performance when compared to FAO56-Penman-Monteith equation during the period of October to March. In the Figures
$2 \mathrm{c}$ and 2a, it can be observed that the Makkink and Hargreaves methods underestimated and overestimated the FAO56Penman-Monteith equation over 1 and $3 \mathrm{~mm}$.day ${ }^{-1}$, respectively. Under these threshold values, the slope of straight line is near 1 and coincides perceptibly to the intercept equal to zero, which indicates the good performances of these methods. The Priestley-Taylor method always overestimates FAO56-PenmanMonteith equation (Figure 2b).

Table 3 shows the results for comparing the six evaluated methods for estimating evapotranspiration with respect to FAO56-Penman-Monteith equation in the period from April to September during the 11 years of considered data. 


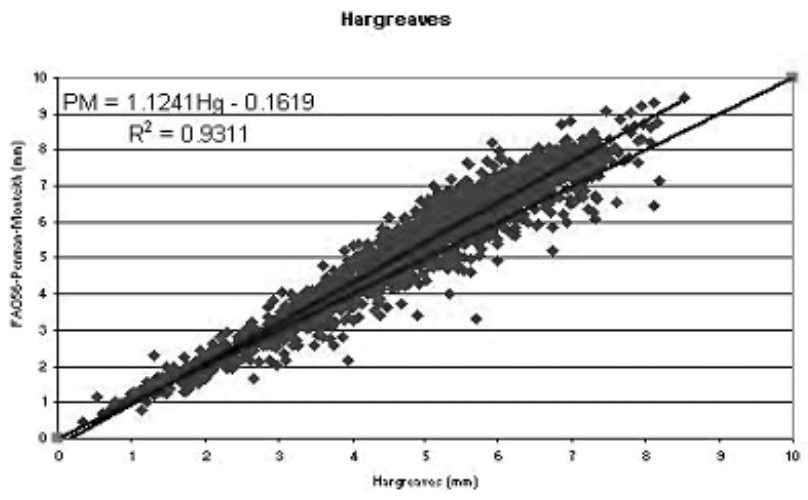

(a)

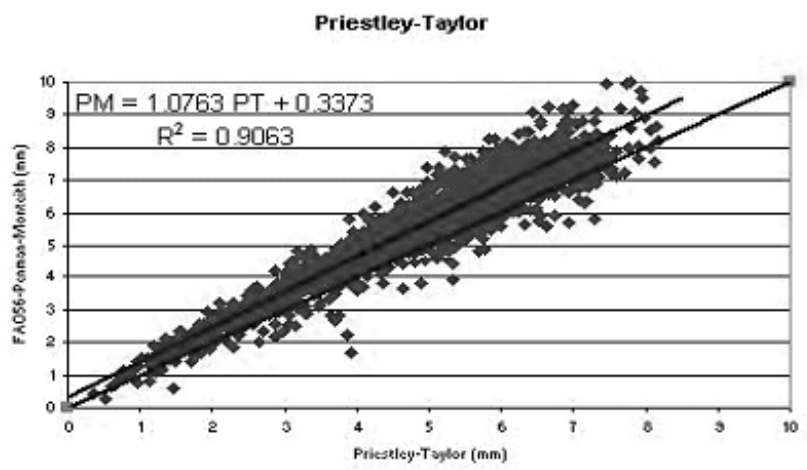

(b)

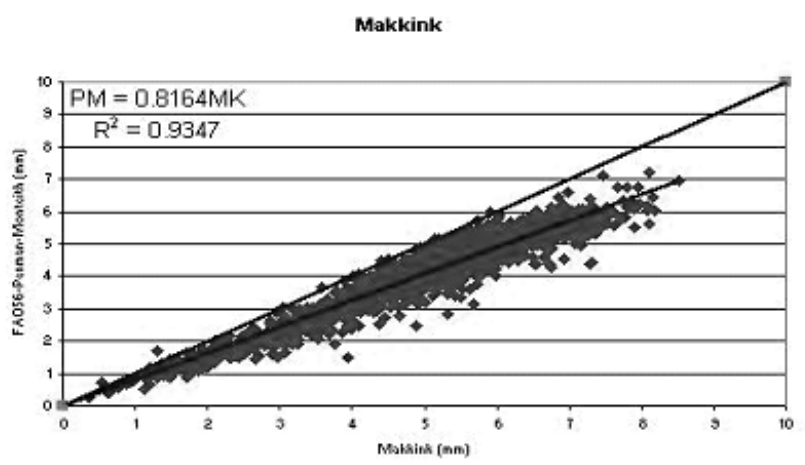

(c)

Figure 2 - Comparison between ETo values estimated by FAOPenman-Monteith equation and those calculated for the three methods that performed the best in the period of high evaporative demand (months of October to March).

Once again the results are similar to the period which takes into account the entire year. The Hargreaves, PriestleyTaylor and Makkink methods presented the highest coefficient of determination and indices of agreement, with values around 0.8 and 0.9 , respectively. Their RMSE and relative error were less than $1 \mathrm{~mm} \cdot$ day $^{-1}$ and 20\%, respectively. Hargreaves-Samani and Camargo methods presented the second lowest RMSE values (less than $1 \mathrm{~mm}^{-d a y^{-1}}$ ) and relative errors between 20 and $30 \%$ approximately. The coefficient of determination presented values under 0.6. The Jensen-Haise equation presented the highest RMSE (equal to $1.27 \mathrm{~mm}_{\text {.day }}{ }^{-1}$ ), a relative error over $40 \%$, a coefficient of determination over 0.8 and an index of agreement around 0.8 .

The Priestley-Taylor method only overestimated FAO56Penman-Monteith equation by $5 \%$. The methods of Hargreaves and Hargreaves-Samani generated significative overestimations (equal to or greater than $8 \%$ ); Jensen-Haise equation showed the highest overestimation with value equal to $36 \%$; and Camargo and Makkink produced a significative underestimation (around $15 \%)$.

Figure 3 shows graphs of the regressions for the three methods that demonstrated the best performances when compared to FAO56-Penman-Monteith equation during the period of April to September. In Figure 3a, it can be observed that the Hargreaves method always overestimated the FAO56Penman-Monteith equation. The results of Priestley-Taylor method were practically equal to the ones of the equation of FAO56-Penman-Monteith, with a very low overestimation (Figure 3b). The Makkink method underestimates the FAO56Penman-Monteith equation over $2 \mathrm{~mm} \cdot \mathrm{day}^{-1}$. Under this threshold value, the slope of the straight line is near 1 and coincides perceptibly to the intercept equal to zero.

\section{CONCLUSIONS}

First of all, the paper highlights the feasibility of using empirical equations to estimate evapotranspiration in a rigorous manner providing an alternative when full hydrometeorological data is not available, which is the case in different areas and watersheds along the whole country. More specifically, the results showed that the Hargreaves, Priestley-Taylor and Makkink methods presented the highest agreements with respect to the FAO56-Penman-Monteith equation. These methods achieved better performances due to the approach of improving the representation of the effects of the radiative process, since they use solar radiation. These equations also incorporate the water vapor by means of the variable W. Such variable provides information about the atmosphere's capacity to receive the water vapor from the vegetated surface.

On the other hand, the Hargreaves-Samani and Camargo methods showed a significant difference in relation to daily ETo estimated by FAO56-Penman-Monteith equation. These formulations use the extraterrestrial solar radiation to represent the radiative process. However, this information does not take into account the reduction of energy reaching the surface, due 


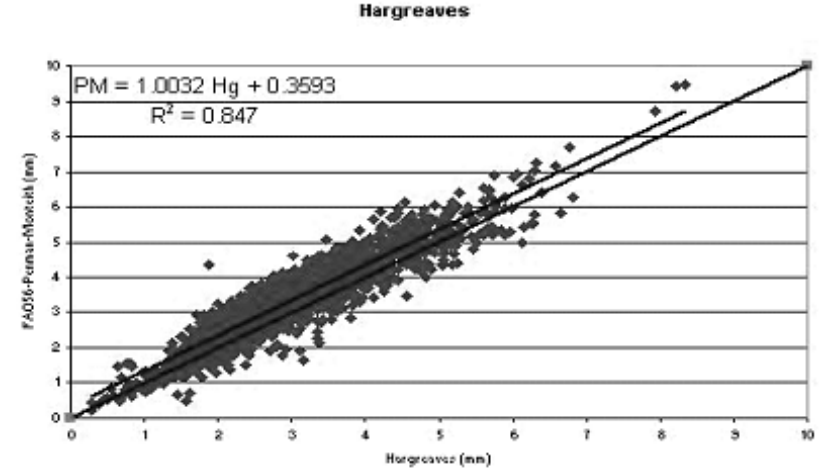

(a)

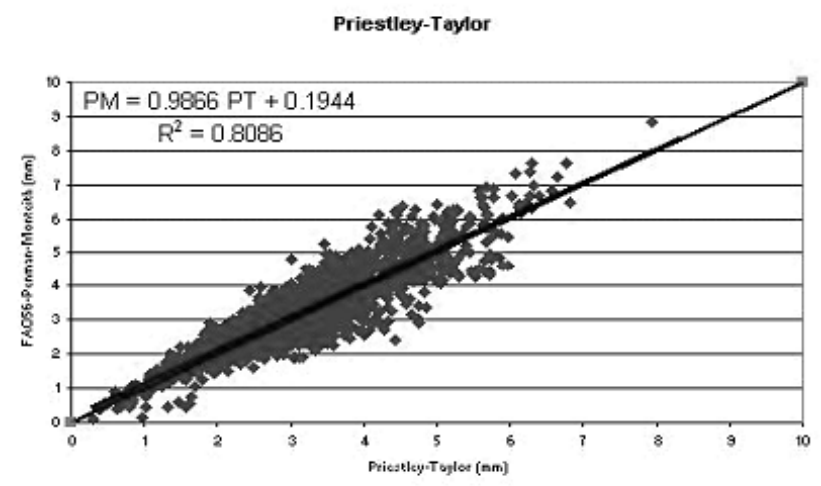

(b)

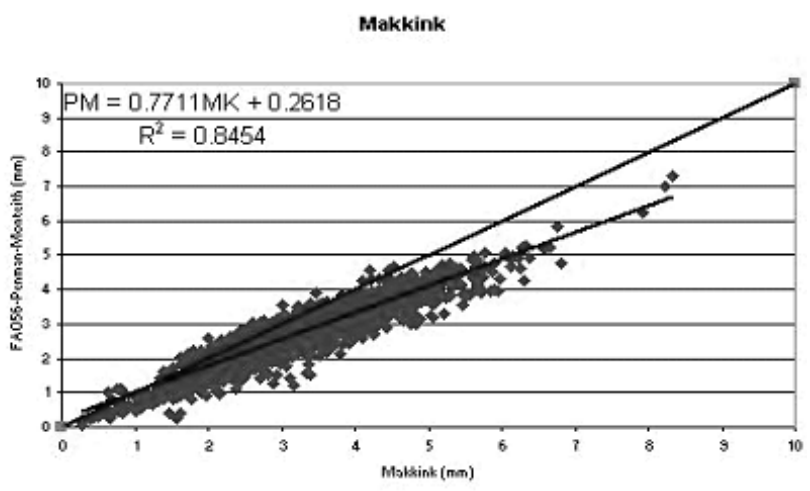

(c)

Figure 3 - Comparison between ETo values estimated by FAOPenman-Monteith equation and those calculated for the three methods that performed the best in the period of low evaporative demand (months of April to September).

to the interaction of radiation with the atmosphere. Moreover, such formulation does not express the advective process.

Although the formulation is similar with respect to the equation of Hargreaves, Jensen-Haise equation produced the worst performance. In this case, the parameterization chosen by the authors may be a plausible explanation. The variables involved in the two equations are the same, changing only the way both equations were written.

The results were pratically identical in the period of high and low demands along the entire year. The Hargreaves, Priestley-Taylor and Makkink methods continued to render the best performance, while Hargreaves-Samani and Camargo equations showed again a significant difference in relation to FAO56-Penman-Monteith. The Jensen-Haise method continued producing the worst estimation for ETo.

Taking daily ETo values of FAO56-Penmam-Monteith equation as a reference, the six methods evaluated can be classified according to their performances, in the following way: Hargreaves, Priestley-Taylor and Makkink produced a good performance and the most precise estimations, while Hargreaves-Samani, Camargo and Jensen-Haise showed a limited performance. Therefore, this study indicates the use of the Hargreaves, Priestley-Taylor and Makkink equations for estimating daily ETo in the studied region.

\section{ACKNOWLEDGEMENTS}

The first author acknowledges the support provided by CNPq through a M. Sc. scholarship granted to carry out this work. In addition, the first author would like to recognize the support of the Instituto Superior de Educação Celso Lisboa for developing this research work. The authors would like also to thank the Civil Engineering Program of Instituto Alberto Luiz Coimbra de Pos-Graduação e Pesquisa de Engenharia (COPPE) - Universidade Federal do Rio de Janeiro (UFRJ) through the support of the Laboratory of Water Resources and Environmental Issues, the Department of Meteorology - Instituto de Geociências (IGEO)/UFRJ, with respect to data and infrastructure provided by these institutions for this research. The authors also recognize the support of Conselho Nacional de Desenvolvimento Científico e Tecnológico $(\mathrm{CNPq})$, through the Programa Sul-Americano de Apoio às Atividades de Cooperação em Ciência e Tecnologia (PROSUL) - Process 490684/2007-6, which deals with remote sensing techniques applied to hydrological monitoring and climate change and the support of Secretaria de Educação Superior (SESu) - Ministério da Educação (MEC) - Coordenação de Aperfeiçoamento de Pessoal de Nível Superior (CAPES) AUX-PE-PET-1228/2009 (PET CIVIL UFRJ), Project PEC/ COPPE - FAPERJ 014/2010 (2010-2012), Project FAPERJ - Process E-26/103.116/2011 (2012-2014), Project IME-PEC/ COPPE - CAPES - Aux-PE-PRO-Defense 1783/2008 (20082012 ) and MCT / FINEP / CT-HIDRO - Representative watersheds 04/2005 (2005-2011). 


\section{REFERENCES}

Allen, R.G., PEREIRA, L.S., SMith, M. Crop evapotranspiration, FAO Irrigation and Dranaige paper 56. Roma. FAORome, 1998.

BARROS, V.R. Avaliação da evapotranspiração utilizando o algoritmo SEBAL e imagens LANDSAT5-TM - Estudo de caso: bacia do rio Piabanha/RJ. 2012. Dissertação (Mestrado em Engenharia Civil) - COPPE, Universidade Federal do Rio de Janeiro. Rio de Janeiro, RJ.

BURMAN, R., Pochop, L.O. Evaporation, evapotranspiration and climatic data. Amsterdan. Elsevier, 1994.

DIAS, N.L., KAN, A. hydrometeorogical model for basin-wide seasonal evapotranspiration, Water Resources Research, v. 35 (11), pp. 3409-3418, 1999.

DIAS, N.L. et al. O método de covariâncias turbulentas atenuadas (MCTA) para medição de fluxos de calor sensível e latente: aplicação ao lago de Itaipu e seu redor, Revista Brasileira de Recursos Hídricos, v. 7 n. 1, pp. $143^{-1} 60$, 2002.

FERNANDES, L.C. Avaliação de diversas equações empíricas de evapotranspiração. Estudo de caso: Campos dos Goytacazes e Ilha do fundão-RJ. 2006142 f. Dissertação (Mestrado em Engenharia Civil) - COPPE, Universidade Federal do Rio de Janeiro. Rio de Janeiro, RJ.
JENSEN, M.E., BURMAN, R., ALLEN, R.G. Evapotranspiration and irrigation water requirements. New York. ASCE, 1990.

LÓPEZ-URREA, R. et al. Testing evapotranspiration equations using lysimeter observations in a semiarid climate, Agricultural water management, v. 85, p. 15-26, 2006.

OUDIN, L., MICHEL, C., ANCTIL, F. Which potential evapotranspiration input for a lumped rainfall-runoff model? Part 1-Can rainfall-runoff models effectively handle detailed potential evapotranspiration inputs? Journal of Hydrology, v. 303, n. 4, pp. 275-289, 2004.

PEREIRA, A.R., ANGEL ${ }^{\circ}$ CCI L.R., SENTELHAS P.C. Agrometeorologia Fundamentos e Aplicações Práticas. Guaíba. Editora Agropecuária, 2002.

PEREIRA, A.C. The Priestley-Taylor parameter and the decoupling factor for estimating reference evapotranspiration. Agricutural and Florestal Meteorology, v. 125, n. 4, pp. 305-313, 2004.

SEDYIAMA, G.C, VILLANOVA, N.A, PEREIRA, A.R. Evapo(transpi)ração. Piracicaba, Editora Universitária ESALQ, 1997. 